\title{
ABSTRAK \\ MODEL STAD (STUDIENT TEAMS ACHIEVEMENT DEVISION) DALAM MENINGKATKAN HASIL BELAJAR COGNITIF SISWA
}

\author{
Muhammad Rijal, Dosen Program Studi Pendidikan Biologi, \\ Fakultas Ilmu Tarbiyah dan Keguruan, IAIN Ambon, \\ 0812452891683, E-mail: rijal_rijal82@yahoo.co.id
}

\begin{abstract}
Berdasarkan hasil penelitian dan pembahasan dapat disimpulkan bahwa "Ada peningkatan hasil belajar peserta didik pada konsep sistem pernapasan di kelas XI IPA 4 SMA Negeri 11 Ambon melalui penerapan model STAD (Studient Teams Achievement Devision) sebesar 66.4\%".
\end{abstract}

Kata kunci: stad, cognitif, siswa

\section{ABSTRACT \\ MODEL STAD (STUDIENT TEAMS ACHIEVEMENT DEVISION) IN IMPROVING STUDENT LEARNING OUTCOMES COGNITIF}

Based on the research results and discussion can be concluded that the results of the learning improvement of learners on the concept of the respiratory system in class XI IPA 4 SMA Negeri 11 Ambon through the application of models of STAD (Studient Teams Achievement Devision) amounted to $41.3 \%$

keyword: stad, cognitif, student

Ada empat unsur utama proses dari kurikulum untuk disampaikan atau belajar mengajar yaitu tujuan, bahan, dibahas dalam proses belajar mengajar model dan alat,serta penilaian. Tujuan sampai kepada tujuan yang telaah sebagai arah dari proses belajar mengajar ditetapkan (Sabri, 2005). Model dan alat pada hakekatnya adalah rumusan tingkah adalah cara atau atau teknik yang laku yang diharapkan dapat dikuasai oleh digunakan dalam mencapai tujuan, siswa setelah menerima atau menempuh sedangkan penilaian berfungsi sebagai alat pengalaman belajarnya. Bahan adalah untuk mengetahui keberhasilan proses dan perangkat pengetahuan yang dijabarkan hasil belajar peserta didik. 
Salah satu model pembelajaran yang dapat dikembangkan oleh guru adalah pembelajaran kooperatif yang merupakan pembelajaran dimana peserta didik belajar dalam kelompok kecil yang memiliki tingkat kemampuan yang berbeda (Sharan, 2009). Tujuan dari pembelajaran kooperatif adalah menciptakan situasi dimana keberhasilan individu ditentukan atau dipengaruhi oleh keberhasilan kelompoknya. Terdapat beberapa model dalam pembelajaran kooperatif yang menarik diantaranya yaitu model STAD (Studient Teams Achievement Devision) yang di dalamnya terdapat lima langkah, yaitu presentase kelas, pembentukan tim atau kelompok, pemberian kuis, skor kemajuan individu dan penghargaan kelompok (Slavin, 2010).

Berdasarkan uraian diatas maka penulis tertarik untuk melakukan penelitian dengan judul "Penerapan Model STAD (Studient Teams Achievement Devision) Dalam Meningkatkan Hasil Belajar peserta didik Pada Konsep sistem pernapasan Di Kelas XI IPA 4 SMA Negeri 11 Ambon.

\section{METODE PENELITIAN}

\section{Jenis Penelitian}

Jenis penelitian yang digunakan dalam penelitian ini adalah Penelitian Tindana Kelas (PTK), yaitu suatu penelitian tindakan yang dilakukan oleh guru sekaligus sebagai peneliti atau bersama-sama dengan orang lain dengan jalan merancang, melaksanakan, dan merefleksikan tindakan secara kolaboratif dan partisipatif yang bertujuan untuk memperbaiki atau meningkatkan mutu (kualitas) proses pembelajaran di kelas melalui tindakan tertentu dalam suatu siklus.

\section{Lokasi dan Waktu Penelitian}

Lokasi yang digunakan untuk pelaksanaan penelitian ini adalah SMA Negeri 11 Ambon, dan waktu penelitian dilakukan pada bulan September 2013

\section{Subyek Penelitian}

Subyek penelitian adalah peserta didik Kelas XI IPA 4 SMA Negeri 11 Ambon yang berjumlah 25 .

\section{Instrumen Penelitian}

\section{Observasi}

Observasi dilakukan peneliti untuk mengetahuai kondisi awal peserta didik dan untuk mengetahui adanya kesesuaian 
antara perencanaan dan pelaksanaan tindakan

\section{Catatan Lapangan}

Merupakan catatan tertulis tentang apa yang didengar, dilihat, dialami, dan dipikirkan. Catatan lapangan digunakan untuk mengamati hal-hal yang terjadi selama proses pembelajaran di kelas.

\section{Tes}

Penelitian ini terdiri dari dua tes, yaitu pree-tes dilakukan sebelum penerapan model STAD untuk pengetahuan awal peserta didik terkait materi yang akan diajarkan, dan post-tes dengan tujuan untuk melihat hasil belajar peserta didik setelah penerapan model pembelajaran.

\section{Teknik Pengumpulan Data}

Teknik pengumpulan data yang digunakan dimana data diperoleh dari hasil tes awal sebelum penerapan model STAD dan hasil tes akhir siklus I, dengan tujuan hasil tes siklus I peserta didik mampu menguasai indikator pembelajaran.

\section{Rancangan Penelitian}

a. (Perencanaan Tindakan) yaitu menyusun rancangan yang dilaksanakan sesuai dengan temuan masalah dan gagasan awal yang mengacu pada model pembelajaran kooperatif tipe STAD (Studient Teams Achievement Devision).

1. Observasi/Refleksi awal

2. Melakukan pertemuan awal dengan kepala sekolah SMAN 11 Ambon atau wakasek kurikulum dan guru mata pelajaran biologi kelas XI IPA untuk membuat keputusan tentang perencanaan penelitian yang akan dilaksanakan.

3. Menentukan sumber data, membentuk dan menetapkan kelompok.

4. Menetapkan dan merumuskan rancangan tindakan, diantaranya:

a) Menentukan tujuan pembelajaran

b) Menyusun kegiatan pembelajaran dengan menggunakan pendekatan kooperatif learning model STAD dalam meningkatkan hasil belajar.

c) Mengkoordinasi program kerja pelaksanaan tindakan dengan teman/observer.

d) Membuat soal tes awal.

b. (Pelaksanaan Tindakan) yaitu melaksanakan desain model STAD. Dalam usaha ke arah perbaikan setip perencanaan bersifat fleksibel dan siap dilakukan perubahan sesuai dengan apa yang terjadi dalam proses 
pelaksanaan dilapangan. Urutan

kegiatan dalam pelaksanaan tindakan diantaranya:

1. Tes pengetahuan awal

2. Penyajian materi

3. Belajar dalam kelompok: Setelah penyajian materi secara klasikal, peserta didik duduk secara berkelompok seperti yang telah dikelompokan. Setiap kelompok akan diberi tugas berupa permasalahan yang berkaitan dengan materi dan harus dikerjakan oleh peserta didik dengan cara bekerjasama dan saling berdiskusi dalam kelompok. Setiap kelompok mempresentasikan hasil diskusinya.

4. Tes pengetahuan akhir: Setelah melakukan kegiatan belajar dalam kelompok, Guru melakukan kuis secara individu. Soal yang diberikan kepada peserta didik adalah sesuai dengan materi yang selesai dibahas dan skor yang diperoleh dihitung sebagai skor kemajuan individu dan penentuan prestasi belajar untuk menentukan kuantitas belajar individu dan klasikal. Skor kemajuan masing-masing anggota disumbangkan sebagai skor kelompok.

5. Pemberian penghargaan c. (Observasi) dilakukan selama pengamatan tindakan sebagai upaya mengetahui jalannya pembelajaran. Pengamatan dilakukan dibantu oleh guru biologi atau observer yang ikut mengamati jalannya pembelajaran berdasarkan pedoman observasi yang telah disiapkan.

d. (Refleksi) yaitu menganalisis data-data yang diperoleh dari tes akhir, observasi dan catatan lapangan, tahap refleksi meliputi kegiatan memahami, menjelaskan dan menyimpulkan data serta mempertimbangkan apakah siklus telah mencapai kriteria atau belum. Sebagai pelengkap untuk kriteria tindakan yang telah ditentukan, dalam refleksi juga dilakukan penelitian terhadap proses pembelajaran. Hasil analisa data yang dilaksanakan dalam tahap ini dipergunakan sebagai acuan untuk merencanakan siklus berikutnya. Rincian tahapan pada siklus II sama dengan siklus I.

\section{Teknik Analisis Data}

Analisa untuk menghitung persentase dari skor maksimum ideal yang seharusnya dicapai, maka rumus yang digunakan adalah sebagai berikut: 


$$
\mathrm{N}=\frac{\mathrm{R}}{\mathrm{SM}} \times \mathbf{1 O O}
$$

Keterangan:

$\mathrm{N}=$ Nilai yang dicari/yang di harapkan

$\mathrm{R}=$ Skor mentah yang diperoleh

$\mathrm{SM}=$ Skor maksimum ideal

$100=$ Bilangan tetap

Untuk mengetahui hasil belajar yang dicapai oleh peserta didik dengan menggunakan pembelajaran kooperatif model STAD (Studient Teams
Achievement Division), maka harus disesuaikan dengan tabel Pedoman Acuan Patokan (Nana Sudjana, 2002).

\section{Indikator Keberhasilan}

Seorang peserta didik dikatakan harus mencapai ketuntasan individual dan klasikal seperti yang telah ditetapkan oleh kurikulum dimana peserta didik memperoleh nilai Kriteria Ketuntasan Minimum (KKM) pada mata pelajaran biologi di SMAN 11 Ambon yaitu 70.

\section{HASIL PENELITIAN}

\section{Pra Siklus}

Tabel 1. Hasil Tes Awal Pada Materi Sistem Pernapasan

\begin{tabular}{|c|c|c|c|}
\hline Angka & Kualifikasi & Frekuensi & Persentase \\
\hline $80-100$ & Baik Sekali & - & - \\
\hline $66-79$ & Baik & 1 & $4 \%$ \\
\hline $56-65$ & Cukup & 1 & $4 \%$ \\
\hline $40-55$ & Kurang & 1 & $4 \%$ \\
\hline $30-39$ & Gagal & 22 & $88 \%$ \\
\hline Jumlah & & $\mathbf{2 5}$ & $\mathbf{1 0 0 \%}$ \\
\hline
\end{tabular}

Sumber Data : Data Primer Hasil Penetitian

Dari hasil test yang dikerjakan oleh peserta didik, setelah diadakan koreksi maka didapatkan hasil yang kurang memuaskan. Hasil koreksi pree test dari 25 peserta didik, di dapatkan perolehan nilai tes awal menunjukan bahwa tidak ada peserta didik yang menguasai indikator pembelajaran dengan kategori baik sekali. (1) 22 orang peserta didik (88\%) kurang menguasai indikator pembelajaran, (2), 1 orang peserta didik

menguasai indikator

pembelajaran dengan kategori kurang,(3), 1 orang peserta didik (4\%) mampu menguasai indikator pembelajaran dengan kategori cukup, (4) 1 orang peserta didik mampu menguasai indikator pembelajaran dengan kategori nilai baik. Sehingga peserta didik yang memenuhi standar nilai (KKM) yang ditetapkan yaitu 70 hanya 1 orang peserta didik. Dari paparan hasil nilai yang didapatkan peserta didik maka tampak bahwa kemampuan awal peserta 


\section{Hasil Penelitian Siklus I}

Tabel 2. Perbandingan Hasil Pree Test dan Post Test Siklus I

\begin{tabular}{|c|c|c|c|}
\hline Angka & Kualifikasi & $\begin{array}{c}\text { Frekuensi Tes } \\
\text { Akhir }\end{array}$ & Persentase \\
\hline $80-100$ & Baik Sekali & 22 & $88 \%$ \\
\hline $66-79$ & Baik & 3 & $12 \%$ \\
\hline $56-65$ & Cukup & - & - \\
\hline $40-55$ & Kurang & - & - \\
\hline $30-39$ & Gagal & - & - \\
\hline Jumlah & & $\mathbf{2 5}$ & $\mathbf{1 0 0} \%$ \\
\hline
\end{tabular}

Sumber Data : Data Primer Hasil Penelitian

Pada tabel diatas terlihat bahwa:

Berdasarkan analisis data hasil

(1). tidak ada peserta didik (0\%) yang belajar dan persentase pada siklus I menguasai indikator pembelajaran dengan terlihat bahwa peserta didik dalam kategori gagal, kurang dan cukup, (2). kegiatan belajar mengajar dari kategori sebanyak 3 orang peserta didik (12\%) cukup, kategori kurang dan kategori mampu menguasai indikator pembelajaran gagal meningkat menjadi kategori baik dengan kategori baik, (3). sebanyak 22 dan kategori baik sekali, serta tingginya orang peserta didik (88\%) mampu hasil belajar peserta didik yang telah menguasai indikator pembelajaran dengan mencapai standar ketuntasan belajar kategori baik sekali. hal ini maksimum secara individu dan klasikal menggambarkan bahwa peserta didik yang ditentukan kurikulum. Akibatnya mampu menguasai indikator sebanyak 25 penelitian tindakan kelas (PTK) di kelas orang peserta didik $(100 \%)$.

XI IPA SMA Nenegi 11 Ambon dianggap selesai pada siklus I. 


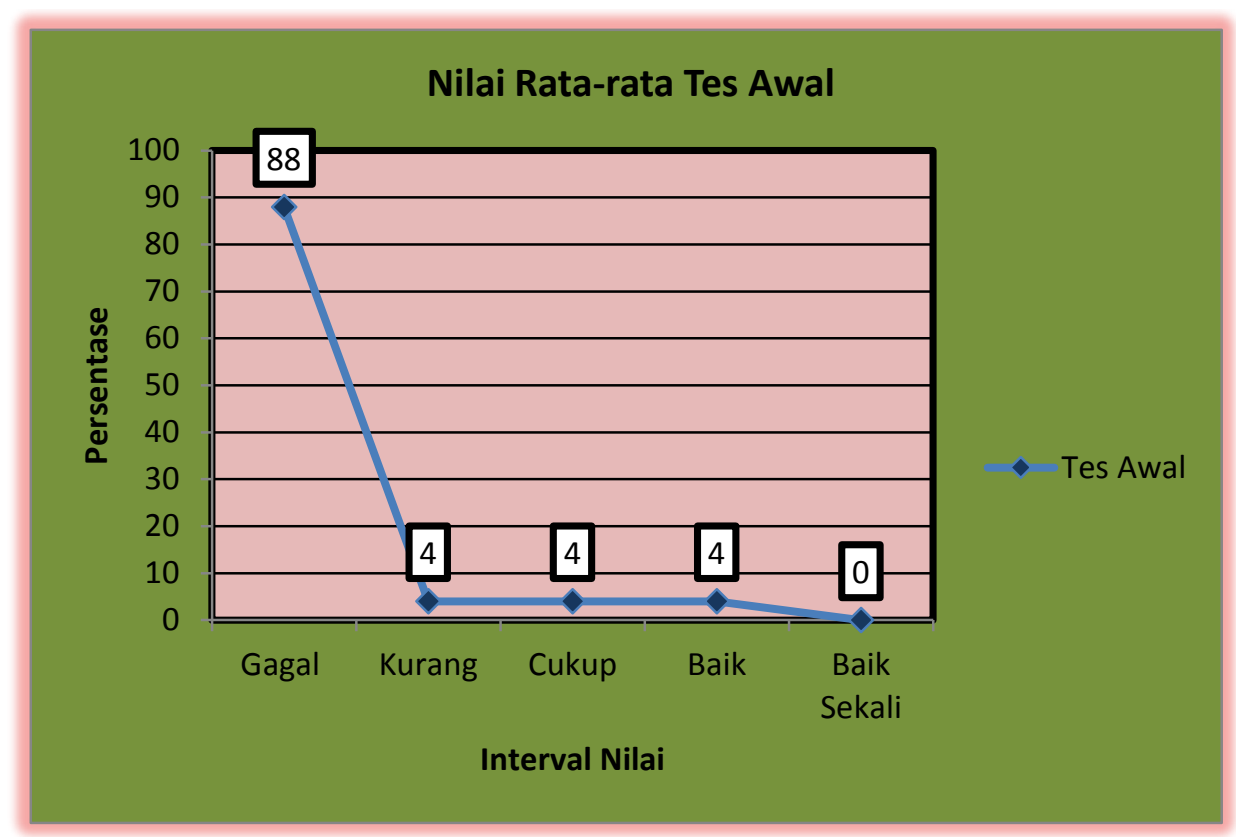

Gambar 1. Grafik nilai rata-rata tes awal

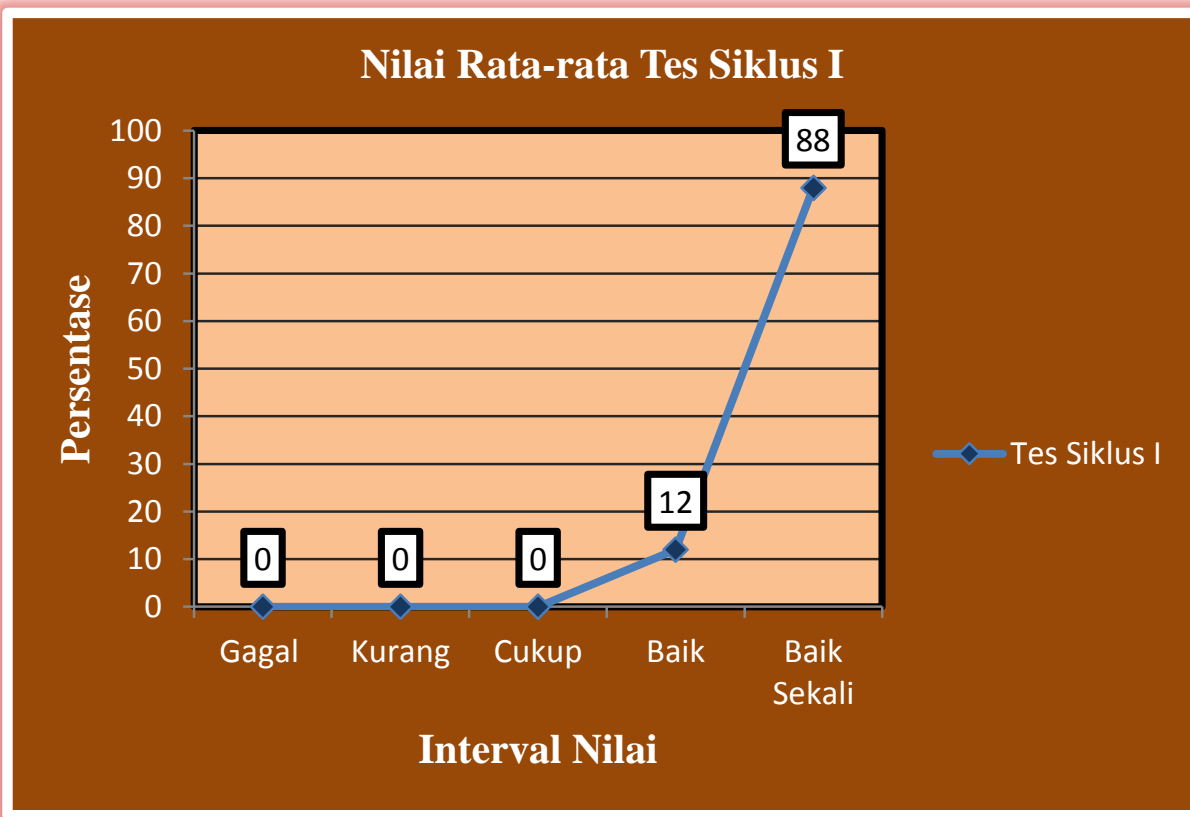

Gambar 2. Grafik nilai rata-rata tes akhir siklus I

Peningkatan rata-rata test awal dan PEMBAHASAN

test akhir siklus I pada materi sistem pernapasan dapat dilihat pada grafik.
Hasil belajar peserta didik sebelum penerapan model STAD, (Pree-test) yaitu 
dari 25 peserta didik SMAN 11 Ambon melalui tes yang dilakukan, diperoleh hasil bahwa 22 orang peserta didik (88\%) memperoleh nilai gagal, 1 orang peserta didik (4\%) memperoleh nilai kurang, 1 orang peserta didik (4\%) memperoleh nilai cukup, 1 orang peserta didik (4\%) memperoleh nilai baik dan tidak ada peserta didik yang memperoleh nilai baik sekali, total jumlah nilai pree-test yaitu 690 sedangkan nilai rata-rata yang diperoleh adalah (27.60\%). Disimpulkan bahwa peserta didik yang berhasil menyelasaikan soal pree-test dan mencapai nilai $\mathrm{KKM}$ berjumlah 1 orang $(4 \%)$.

Hasil belajar peserta didik setelah penerapan model STAD, (Post-test) yaitu dari 25 peserta didik SMA 11 Ambon melalui tes yang dilakukan, diperoleh hasil bahwa tidak ada peserta didik $(0 \%)$ yang memperoleh nilai gagal, kurang dan cukup, 3 orang peserta didik (12\%) memperoleh nilai baik, dan 22 orang peserta didik (88\%) memperoleh nilai baik sekali. Total jumlah nilai post-test siklus I yaitu 2350, sedangkan nilai ratarata yang diperoleh adalah (94.00\%). Disimpulkan bahwa peserta didik yang berhasil menyelesaikan soal post-tes dan mencapai nilai KKM berjumlah 25 orang $(100 \%)$.

\section{KESIMPULAN}

Berdasarkan hasil penelitian dan pembahasan dapat disimpulkan bahwa "Ada peningkatan hasil belajar peserta didik pada konsep sistem pernapasan di kelas XI IPA SMA Negeri 11 Ambon melalui penerapan model STAD sebesar $66.4 \% "$

\section{SARAN}

Sehubungan dengan kesimpulan yang dikemukakan di atas, maka peneliti menyarankan kepada para guru maupun calon guru agar hendaknya memilih model pembelajaran yang tepat agar proses belajar mengajar berjalan sesuai dengan yang diinginkan dan mudah dipahami oleh peserta didik, salah satunya adalah model pembelajaran kooperatif tipe STAD sehingga dapat memicu motivasi dan kerjasama peserta didik dalam belajarnya.

\section{DAFTAR PUSTAKA}

Arikunto, Suharsimi. 2002. Dasar-Daras Evaluasi Pendidikan. PT Bumi Aksara. Jakarta. --. 2002. Prosedur Penelitian Suatu Pendekatan Praktek. PT. Remaja Rosdakarya. Jakarta. 
De Porter, Bobbi \& Mike Hernacki. 2007. Quantum Lerning: Membiasakan Belajar Nyaman dan Menyenangkan. Mizam Pustaka. Bandung.

Ihsan, Fuad. 2010. Dasar-Dasar Pendidikan. Rineka Cipta. Jakarta.

Achmad Zulfah \& Juwono. 2003. Biologi Sel. Penerbit Buku Kedokteran. Jakarta.

Sabri, Ahmad. 2005. Strategi Belajar Mengajar Micro Teaching. Quantum Teaching. Jakarta

Sharan, Shlomo. 2009. Haanbook of Cooperatif Learning. Imperium. Yogyakarta.

Slameto. 2003. Belajar dan Faktor-Faktor Yang Mempengaruhinya. Rineka Cipta. Jakarta.

Slavin, Robert E.,. 2010. Cooperatif Learning: Teori, Riset dan Praktek. Nusa Media. Bandung.

Sobur, Alex. 2003. Psikologi Umum. Pustaka Setia. Bandung.

Sudjana, Nana.2001. Penilaian Hasil Proses Belajar Mengajar. PT Remaja Rosdakarya. Bandung.

Yoni, Acep. 2010. Menyusun Penelitian Tindakan Kelas. Familia. Yogyakarta. 